\title{
Haploidentical transplantation of hematopoietic stem cells
}

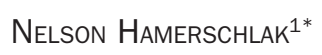

Nelson Hamerschlak ${ }^{1 *}$

${ }^{1}$ Tenured Professor at Universidade de São Paulo. Medical Coordinator of the Hematology and Bone Marrow Transplantation Program of Hospital Israelita Albert Einstein

\section{SUMMARY}

Objective: To review and discuss the literature on hematopoietic stem cell transplantation (HSCT) with haploidentical donors in Brazil.

Method: Literature review.

Results: The haploidentical hematopoietic stem cell transplantations have become a safe option in hematology since the $80 \mathrm{~s}$, with the possibility of ex-vivo T-cell depletion. However, its broad use worldwide occurred with the advent of haploidentical nonmyeloablative transplants using in vivo T-cell depletion with the administration of post-transplant cyclophosphamide. The results were encouraging, despite the increased risk of infection and post-transplantation recurrence. Recent publications on acute myeloid leukemia, myelodysplastic syndrome and Hodgkin's lymphoma have shown similar results among haploidentical, unrelated and related full-match transplants. Obviously, these findings of retrospective studies should be confirmed by clinical trials.

Conclusions: Transplantation with haploidentical donor has shown to be feasible in Brazil and the first publications and results are showing encouraging results.

Keywords: Bone Marrow Transplantation. Stem cells. Transplants.

\section{INTRODUCTION}

The haploidentical transplantation initiatives in the 1970s were catastrophic and prohibitive, with an incidence of graft-versus-host-disease (GVHD) $>70 \%$ and grafting failure of $20 \% .^{1}$ In the 1980 s, with the use of T-cell depletion with sheep erythrocytes, the methodology started to show greater acceptance. ${ }^{1}$

In 1994, the Italian group with the CD34 cell selection equipment, demonstrated decreased risk of rejection using high doses of cells ("mega dose": $13.8 \times 10^{6} \mathrm{CD} 34$ with $1 \times 10^{4}$ CD3). ${ }^{2}$ The initiatives of Chinese researchers with stringent conditioning have shown excellent results since 2006. ${ }^{3}$ In 2007, the Duke University group led by Nelson Chao presented a protocol without selection of CD34+ cells in vitro and in vivo depletion using Campath (alemtuzumab) in the conditioning regimen. ${ }^{4}$ However, a major breakthrough occurred in 2008 when the group of Baltimore, led by Ephraim Fuchs, consolidated the use of cyclophosphamide on days +3 and +4 post-transplantation, also with depletion of $\mathrm{T}$ cells in vivo. ${ }^{5}$ The authors published results using this type of regimen in several types of malignant diseases, such acute myeloid leukemia, acute lymphoblastic leukemia, myelodysplasia and non-Hodgkin and Hodgkin's lymphoma, with an overall survival $>50 \%$ in Hodgkin's lymphoma, reaching 76\%. ${ }^{5}$ From that point onward, what we saw was a constant search for methodologies that would further improve the results of haploidentical transplants..$^{5-7}$

The advantages of using this type of transplant is the immediate donor availability, instant access to the donor for cell therapy after transplantation and the possibility of selecting several family members according to clinical characteristics and alloreactivity of NK (natural killer) cells. As disadvantages, we can mention the higher potential risk of GVHD, the need for depletion of $\mathrm{T}$ cells in vivo or ex vivo, leading to a higher incidence of infection due to the slow immuno-reconstitution and high incidence of recurrence. ${ }^{6,7}$

But undoubtedly, the great advantage is that, considering that $40-50 \%$ of patients have no related or unrelated compatible donors, HLA "mismatch" or haploidentical transplants of first-degree relatives can be found in over $95 \%$ of patients. ${ }^{7-9}$

In Brazil, the use of post-transplantation cyclophosphamide is the one most often used to perform haploidentical transplants. This choice is not made by chance. 
First, it results from the high cost of processing, which is restricted to a few treatment centers that have specific protocols to be used in, for instance, congenital immunodeficiencies. Secondly, literature reports indicate that the results tend to be better, since only alloreactive lymphocytes are affected. ${ }^{5,8,9,10}$

Initial studies seeking to compare the haploidentical transplantation with other alternatives, such the umbilical cord or unrelated mismatch transplants, have not shown great superiority between one form or another of transplanting. Given that factors such as mismatch, presence of anti-HLA antibodies, KIR reactivity, NIMA and HLA C in umbilical cord can help in the decision-making, Table 1 has been widely used as a guide. ${ }^{11-15}$

Recently, the MD Anderson group, led by Dr. Stefan Ciurea, showed comparable results between haploidentical and unrelated transplants, even fully compatible. This fact opens the possibility of using the haploidentical transplant primarily when compatible related donor cannot be found and when it takes longer to find unrelated donors due to genetic or operational difficulties. This finding, which has been demonstrated by other groups, will obviously change - if confirmed by clinical studies - the way we choose the best donor for hematopoietic cell transplantation, significantly modifying Table 1 and establishing the haploidentical transplant option or unrelated transplant as fully compatible for most clinical situations ${ }^{16,17}$.

\section{Advantages AND Disadvantages OF USING HAPLOIDENTICAL DONORS}

Compared to other sources of donors, the main advantages of using haploidentical transplants are: $6,7,9$

a) Availability: it is estimated that a patient has 2.7 potential haploidentical donors among their firstdegree relatives. This number is compared to a 25 to $30 \%$ chance of an HLA-identical family donor and the variable chances between $16 \%$ and $75 \%$ of a fully compatible donor $(8 \times 8)$ in a donor registry, depending on the genetic difficulty of each case.

b) Immediate availability: in urgent cases, when compatible family donors cannot be found, a haploidentical donor will be selected quickly, compared with the mean time for search and confirmation of an unrelated donor, which is around three to four months.

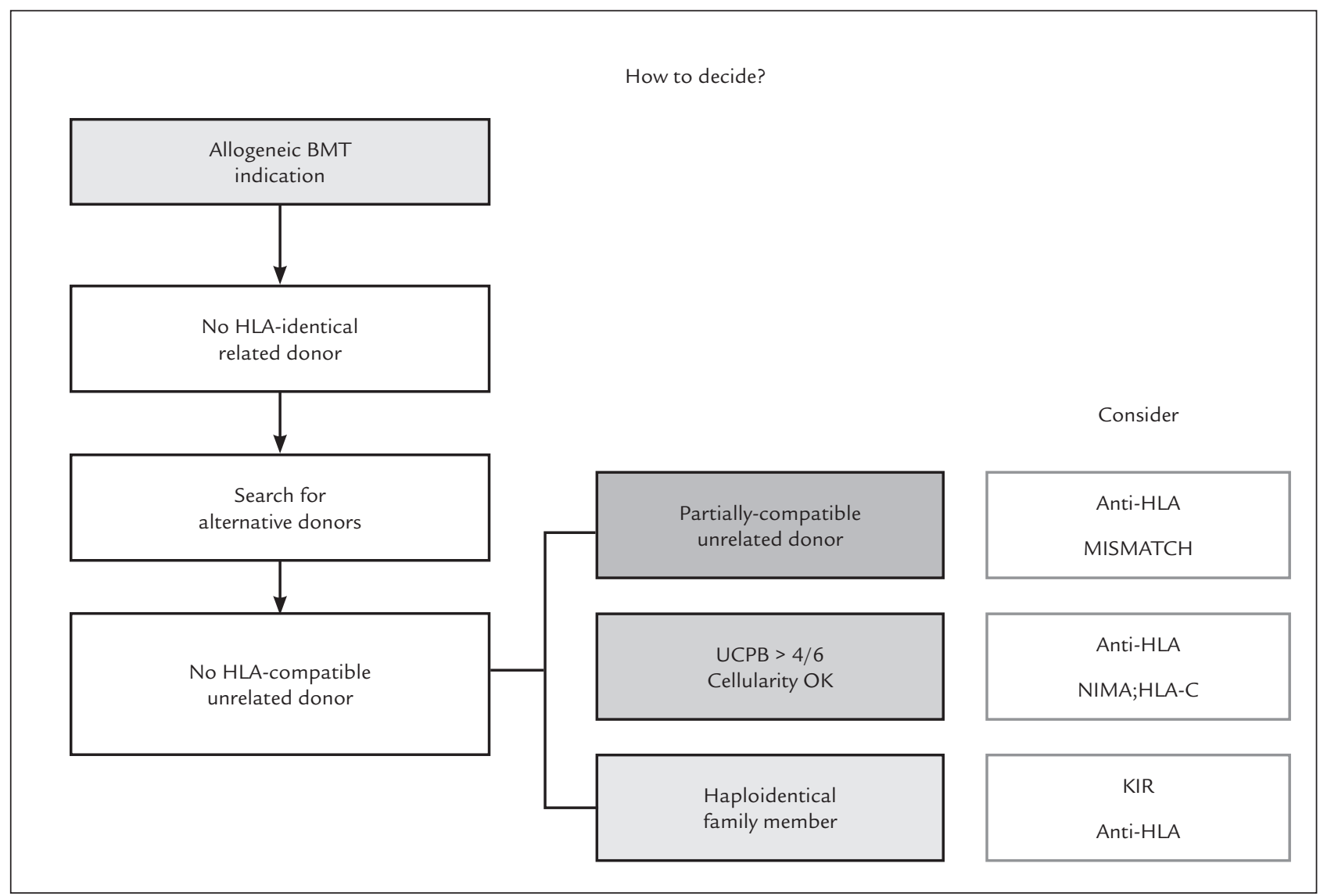

CHART 1. Decision process between alternative transplants 
c) Low cost: compared with unrelated donors and umbilical cord blood, the costs are significantly lower in the search for haploidentical donors.

d) Possibility of using the donor cells for immunotherapy (lymphocyte infusion): this strategy is impossible in the case of umbilical cords.

However, the use of methods that target T-cell depletion decreases the incidence of GVHD, but increases the risk of rejection, infection and reduces graft-versus-leukemia reaction. ${ }^{11-13}$

\section{Main CuRRent strategies for HAPLOIDENTICAL TRANSPLANTS}

a) In vitro T-cell depletion: This methodology employs megadoses of CD34 and is used by the Perugia group. ${ }^{1,2,12,13}$

b) GIAC: uses G-CSF (G) granulocyte colony stimulating factor to stimulate the donor and extensive post-transplantation immunosuppression (I), using ATG (A) (antithymocyte globulin) and the combined use $(\mathrm{C})$ of bone marrow and peripheral blood. This methodology is used almost exclusively in China, where there is extensive experience in haploidentical transplants. ${ }^{13}$

c) Post-transplantation cyclophosphamide: this is the main form of T-cell depletion used worldwide, with adaptations to the first works with non-myeloablative transplants using fludarabine, low-dose (200 Gy) total body irradiation and cyclophosphamide. Cyclophosphamide $50 \mathrm{mg} / \mathrm{kg}$ is used on days +3 and +4 and the prophylaxis of graft-versus-host disease is made with MMF and tacrolimus. ${ }^{4,16,18}$

d) Choice of the best donor: According to a study published by the Chinese group, the best donor is young and male. ${ }^{19}$ The father has precedence over the mother. It is also important to assess the blood group, perform serology for cytomegalovirus, assess the presence of HLA donor-specific antibodies, NIMA (non-inherited maternal antigens) and KIR reactivity. ${ }^{20}$ These data have not been reproduced by others and we do not know whether their use is valid for other conditioning regimens. The most important factor in all the works and for any type of methodology, is the assessment of the presence of anti-donor specific antibodies.

\section{BRAZILIAN EXPERIENCE WITH HAPLOIDENTICAL TRANSPLANTATION}

The number of haploidentical transplants have been increasing in Brazilian centers. Until mid-2013, 85 transplants had been performed. From that date until mid-2015, over 100 transplants were performed, totaling 185 cases and this number is increasing. ${ }^{21}$ Most were performed in cases of acute leukemia ( 90 patients), severe aplastic anemia (24 patients) and Hodgkin's lymphoma (20 patients), with the remaining patients scattered among other indications of malignant and nonmalignant diseases. The overall survival of these patients can be seen in Graph 1. The presence of hepatic veno-occlusive disease was the only factor that had an impact on survival in the multivariate analysis of Brazilian cases as shown in Table $1 .^{21}$

Regarding specific initiatives, the Brazilian group published a series of severe aplastic anemia cases (16 patients) with interesting results (Graph 2) and presented the results of 20 patients with Hodgkin's lymphoma

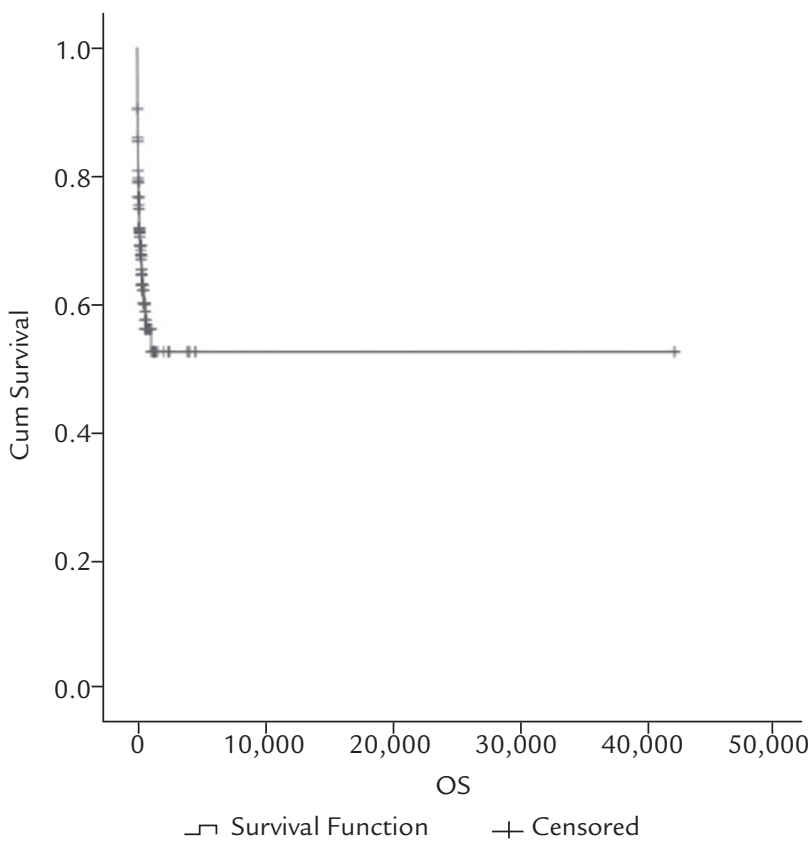

GRAPH 1. Overall survival of patients undergoing haploidentical transplants in Brazil ${ }^{21}$

TABLE 1. Multivariate analysis of impact on survival ${ }^{21}$

\begin{tabular}{lll} 
Variable & $\begin{array}{l}\text { Hazard } \\
\text { ratio }\end{array}$ & $\mathrm{P}$ \\
\hline Diagnosis & & \\
\hline Lymphoma/Myeloma (versus non-malignant) & 1.99 & 0.625 \\
\hline Acute leukemia (versus non-malignant) & 2.28 & 0.12 \\
\hline Age (contínua) & 1.01 & 0.10 \\
\hline High-risk disease (versus standard risk) & 1.16 & 0.63 \\
\hline Bone marrow use (versus peripheral blood) & 1.22 & 0.49 \\
\hline Myeloablative conditioning & 1.00 & 0.98 \\
\hline Total body irradiation use & 0.70 & 0.48 \\
\hline Onset of hepatic veno-occlusive disease & 2.85 & 0.008 \\
\hline Chronic GVHD (time-dependent) & 0.87 & 0.78 \\
\hline
\end{tabular}

$\mathrm{GVHD}=$ graft-versus-host disease 
(Figure 3) at the Congress of the Brazilian Association of Hematology (ABHH) in 2015.22,23 The main initiatives in haploidentical transplants of the Brazilian Society of Bone Marrow Transplantation (SBTMO) were established at the society meetings, with members interested in the area and the creation of uniform protocols for the following situations: acute myeloid leukemia and myelodysplasia, acute lymphocytic leukemia, Hodgkin's lymphoma and severe aplastic anemia. ${ }^{24}$

\section{Conclusion}

The haploidentical transplantation is a type of procedure that has become more and more popular among spe-

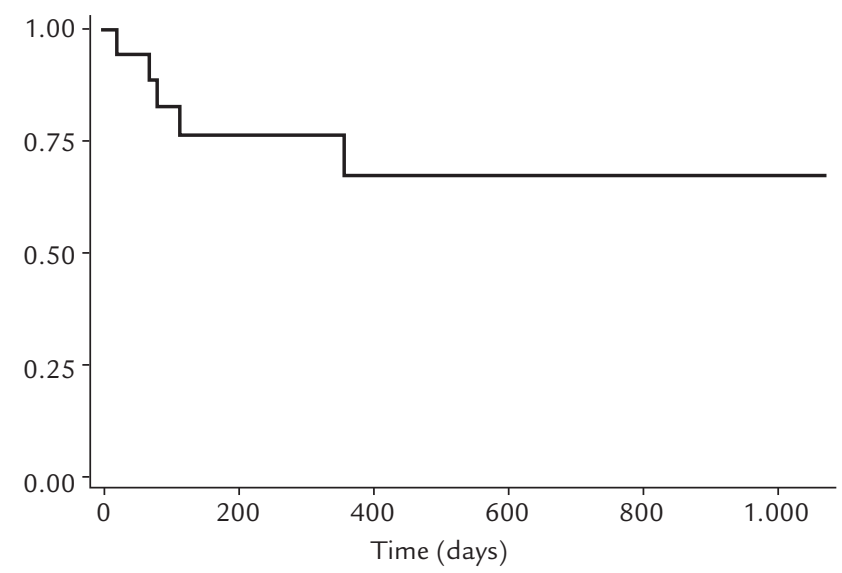

Bone Marrow Transplantation 50, 685-689 (May 2015)

GRAPH 2. Overall survival in severe aplastic anemia: $67.1 \%$ (95\% confidence interval: $36.5 \%-85.4 \%) .{ }^{22}$

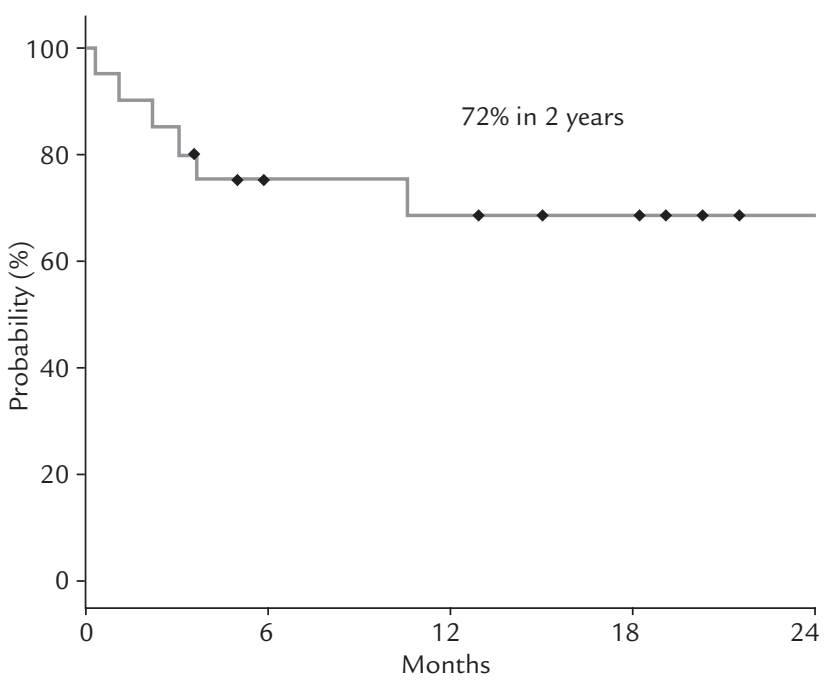

Lacerda MP, Rodrigues CA, Rocha V et al submitted ABHH 2015

GRAPH 3. Overall survival in Hodgkin's Lymphoma. ${ }^{23}$ cialists in the area. The use of post-transplant cyclophosphamide has popularized its use. In some pathologies, the results are as good as in related and unrelated transplants. In Brazil, its use has gained much acceptance.

\section{Resumo}

Transplantes haploidênticos de células-tronco hematopoieticas

Objetivo: Revisar e discutir a literatura sobre transplantes de células-tronco hematopoiéticas (TCTH) com doador haploidêntico no Brasil.

Métodos: Revisão da literatura médica.

Resultados: Os transplantes haploidênticos de células-tronco hematopoiéticas tornaram-se uma opção segura na hematologia a partir dos anos 1980, com a possibilidade de depleção de células T ex-vivo. No entanto, sua ampla utilização em todo mundo ocorreu após os trabalhos com os transplantes haploidênticos não mieloablativos, com depleção de células $\mathrm{T}$ in-vivo, utilizando ciclofosfamida pós-transplante. Os resultados se mostraram encorajadores, apesar do maior risco de infecções e recidiva pós-transplante. Estudos em determinadas patologias, principalmente na leucemia mieloide aguda, mielodisplasia e linfoma de Hodgkin, mostram resultados semelhantes entre transplantes haploidênticos e não aparentados e aparentados totalmente compatíveis. Logicamente, esses achados de estudos retrospectivos precisam ser confirmados por estudos clínicos.

Conclusões: No Brasil, a modalidade de transplante com doador haploidêntico se mostrou factível e as primeiras publicações e resultados mostram resultados animadores.

Palavras-chave: Transplante de medula óssea. Célulastronco. Transplantes.

\section{RefEREnCES}

1. Reisner Y, Kapoor N, Kirkpatrick D, Pollack MS, Dupont B, Good RA, et al Transplantation for acute leukaemia with HLA-A and B nonidentical parental marrow cells fractionated with soybean agglutinin and sheep red blood cells. Lancet. 1981;2(8242):327-31.

2. Aversa F, Tabilio A, Terenzi A, Velardi A, Falzetti F, Giannoni C, et al. Successful engraftment of T-cell-depleted haploidentical "three-loci" incompatible transplants in leukemia patients by addition of recombinant human granulocyte colony-stimulating factor-mobilized peripheral blood progenitor cells to bone marrow inoculum. Blood. 1994;84(11):3948-55.

3. Lu DP, Dong L, Wu T, Huang XJ, Zhang MJ, Han W, et al. Conditioning including antithymocyte globulin followed by unmanipulated HLAmismatched/haploidentical blood and marrow transplantation can achieve comparable outcomes with HLA-identical sibling transplantation. Blood. 2006;107(8):3065-73

4. Rizzieri DA, Koh LP, Long GD, Gasparetto C, Sullivan KM, Horwitz M, et al. Partially matched, nonmyeloablative allogeneic transplantation: clinical outcomes and immune reconstitution. J Clin Oncol. 2007;25(6):690-7. 
5. Luznik L, O’Donnell PV, Symons HJ, Chen AR, Leffell MS, Zahurak M, et al. HLA-haploidentical bone marrow transplantation for hematologic malignancies using nonmyeloablative conditioning and high-dose, posttransplantation cyclophosphamide. Biol Blood Marrow Transplant. 2008;14(6):641-50.

6. Di Ianni M, Falzetti F, Carotti A, Terenzi A, Del Papa B, Perruccio K, et al. Immunoselection and clinical use of T regulatory cells in HLA-haploidentical stem cell transplantation. Best Pract Res Clin Haematol. 2011;24(3):459-66.

7. Raiola AM, Dominietto A, di Grazia C, Lamparelli T, Gualandi F, Ibatici A, et al. Unmanipulated haploidentical transplants compared with other alternative donors and matched sibling grafts. Biol Blood Marrow Transplant. 2014;20(10):1573-9.

8. Wang Y, Liu DH, Xu LP, Liu KY, Chen H, Chen YH, et al. Superior graftversus-leukemia effect associated with transplantation of haploidentical compared with HLA-identical sibling donor grafts for high-risk acute leukemia: an historic comparison. Biol Blood Marrow Transplant. 2011;17(6):821-30.

9. Kasamon YL, Luznik L, Leffell MS, Kowalski J, Tsai HL, Bolaños-Meade $\mathrm{J}$, et al. Nonmyeloablative HLA-haploidentical bone marrow transplantation with high-dose posttransplantation cyclophosphamide: effect of HLA disparity on outcome. Biol Blood Marrow Transplant. 2010;16(4):482-9.

10. Shabbir-Moosajee M, Lombardi L, Ciurea SO. An overview of conditioning regimens for haploidentical stem cell transplantation with post-transplantation cyclophosphamide. Am J Hematol. 2015;90(6):541-8.

11. Bashey A, Zhang X, Sizemore CA, Manion K, Brown S, Holland HK, et al. T-cell-replete HLA-haploidentical hematopoietic transplantation for hematologic malignancies using post-transplantation cyclophosphamide results in outcomes equivalent to those of contemporaneous HLA-matched related and unrelated donor transplantation. J Clin Oncol. 2013;31(10):1310-6.

12. Aversa F, Tabilio A, Terenzi A, Velardi A, Falzetti F, Giannoni C, et al. Successful engraftment of T-cell-depleted haploidentical "three-loci" incompatible transplants in leukemia patients by addition of recombinant human granulocyte colony-stimulating factor-mobilized peripheral blood progenitor cells to bone marrow inoculum. Blood. 1994;84(11):3948-55.

13. Aversa F, Tabilio A, Velardi A, Cunningham I, Terenzi A, Falzetti F, et al. Treatment of high-risk acute leukemia with T-cell-depleted stem cells from related donors with one fully mismatched HLA haplotype. N Engl J Med. 1998;339(17):1186-93

14. Aversa F, Terenzi A, Tabilio A, Falzetti F, Carotti A, Ballanti S, et al. Full haplotypemismatched hematopoietic stem-cell transplantation: a phase II study in patients with acute leukemia at high risk of relapse. J Clin Oncol. 2005;23(15):3447-54.
15. Huang XJ, Liu DH, Liu KY, Xu LP, Chen H, Han W, et al. Haploidentical hematopoietic stem cell transplantation without in vitro T-cell depletion for the treatment of hematological malignancies. Bone Marrow Transplant. 2006;38(4):291-7.

16. Liu D, Huang X, Liu K, Xu L, Chen H, Han W, et al. Haploidentical hematopoietic stem cell transplantation without in vitro $\mathrm{T}$ cell depletion for treatment of hematological malignancies in children. Biol Blood Marrow Transplant. 2008;14(4):469-77.

17. Ciurea SO, Zhang MJ, Bacigalupo AA, Bashey A, Appelbaum FR, Aljitawi OS, et al. Haploidentical transplant with posttransplant cyclophosphamide vs matched unrelated donor transplant for acute myeloid leukemia. Blood. 2015;126(8):1033-40.

18. Brunstein CG, Fuchs EJ, Carter SL, Karanes C, Costa LJ, Wu J, et al. Alternative donor transplantation after reduced intensity conditioning: results of parallel phase 2 trials using partially HLA-mismatched related bone marrow or unrelated double umbilical cord blood grafts. Blood. 2011;118(2):282-8.

19. Wang Y, Chang YJ, Xu LP, Liu KY, Liu DH, Zhang XH, et al. Who is the best donor for a related HLA haplotype-mismatched transplant? Blood. 2014;124(6):843-50.

20. Chang YJ, Zhao XY, Huo MR, Xu LP, Liu DH, Liu KY, et al. Immune reconstitution following unmanipulated HLA-mismatched/haploidentical transplantation compared with HLA-identical sibling transplantation. J Clin Immunol. 2012;32(2):268-60.

21. Esteves I, Seber A, Bonfim C, Ribeiro A, Hamerschlak N on behalf of the Brazilian Group of Haploidentical Transplants (SBTMO) in preparation for publication. In: Congresso Brasileiro de Transplantes de Medula óssea (SBTMO). Foz do Iguaçu; 2015. Resumo.

22. Esteves I, Bonfim C, Pasquini R, Funke V, Pereira NF, Rocha V, et al. Haploidentical BMT and post-transplant $\mathrm{Cy}$ for severe aplastic anemia: a multicenter retrospective study. Bone Marrow Transplant. 2015;50(5):685-9.

23. Lacerda MP, Rodrigues CA, Pereira AD, Novis Y, Fonseca M, Roberto L, et al. Nonmyeloablative HLA-Haploidentical transplantation with high-dose posttransplant cyclophosphamide for relapsed/refractory Hodgkin lymphoma. In: HEMO ABHH (Congresso Brasileiro de Hematologia, Hemoterapia e Terapia Celular, Associação Brasileira de Hematologia, Hemoterapia e Terapia Celular); 2015. Abstract.

24. Hamerschlak N, Bouzas LFS, Seber A, Silla L, Ruiz MA. Diretrizes da Sociedade Brasileira de Transplante de Medula Óssea 2012. São Paulo: Sociedade Brasileira de Transplante de Medula Óssea; 2013. 